ISSN: 2338-4328 (Print), ISSN: 2686-2646 (Online)

Available online at: https://sultanist.ac.id/index.php/sultanist

\title{
PENGARUH LIKUIDITAS DAN PERTUMBUHAN ASET TERHADAP PROFITABILITAS YANG BERDAMPAK PADA NILAI PERUSAHAAN PADA PERUSAHAAN SUB SEKTOR PERTAMBANGAN MINYAK DAN GAS BUMI YANG TERDAFTAR DI BURSA EFEK INDONESIA
}

\author{
Ady Inrawan ${ }^{\left.1^{*}\right)}$, Darwin Lie ${ }^{2)}$, Debi Eka Putri ${ }^{3)}$, Suci Indah Rukmana ${ }^{4}$ \\ Program Studi Manajemen, Sekolah Tinggi Ilmu Ekonomi Sultan Agung \\ *Email: ${ }^{1}$ ady@ @stiesultanagung.ac.id, ${ }^{2}$ darwin@ stiesultanagung.ac.id, \\ 32debiekaputri@stiesultanagung.ac.id, ${ }^{4}$ suciindahrukmana@gmail.com
}

\begin{abstract}
Abstrak
Tujuan dari penelitian ini adalah 1. Untuk mengetahui gambaran Likuiditas, Pertumbuhan Aset, Profitabilitas dan Nilai Perusahaan 2. Untuk mengetahui pengaruh Likuiditas dan Pertumbuhan Aset terhadap Profitabilitas 3. Untuk mengetahui pengaruh Profitabilitas terhadap Nilai Perusahaan. Penelitian ini dilakukan dengan metode analisis deskriptif kualitatif dan analisis deskriptif kuantitatif. Objek penelitian ini adalah Perusahaan Sub Sektor Pertambangan Minyak dan Gas Bumi yang Terdaftar di Bursa Efek Indonesia. Pengumpulan data dilakukan dengan metode dokumentasi. Teknik analisis yang digunakan adalah analisis linear berganda, analisis linear sederhana koefisien korelasi, koefisien determinasi dan uji hipotesis. Hasil penelitian ini dapat disimpulkan sebagai berikut: 1. Dari hasil analisis regresi linear berganda diketahui bahwa likuiditas dan pertumbuhan aset berpengaruh negatif terhadap profitabilitas. 2. Dari hasil analisis regresi linear sederhana diketahui bahwa likuiditas dan pertumbuhan aset berpengaruh negatif terhadap profitabilitas, profitabilitas berpengaruh positif terhadap nilai perusahaan. 3. Dari hasil uji koefisien korelasi dan determinasi bahwa terdapat hubungan yang sangat rendah antara likuiditas dan pertumbuhan aset terhadap profitabilitas, terdapat hubungan yang sedang antara profitabilitas terhadap nilai perusahaan. 4. Dari hasil uji F diketahui bahwa likuiditas dan pertumbuhan aset berpengaruh tidak signifikan terhadap profitabilitas. 5. Dari hasil uji t diketahui bahwa likuiditas dan pertumbuhan aset berpengaruh tidak signifikan terhadap profitabilitas, dan profitabilitas berpengaruh signifikan terhadap nilai perusahaan.
\end{abstract}

Kata Kunci: Likuiditas, Pertumbuhan Aset, Profitabilitas dan Nilai Perusahaan

\begin{abstract}
The objectives of this research are: 1. To determine the description of Liquidity, Asset Growth, Profitability and Company Value 2. To determine the effect of Liquidity and Asset Growth to Profitability. 3. To determine the effect of profitability on company value. This research was conducted using qualitative descriptive analysis methods and quantitative descriptive analysis. The Objectives this research used oil and gas mining sub sector companies listed on the Indonesia. The data was collection by using the documentation method. The analysis technique used is the multiple linear regression analysis, simple linear regression analysis, the correlation coefficient, the coefficient of determination and hypothesis testing. The results of this research can be concluded as follows: 1. From the results of multiple linear regression analysis, it is known that liquidity and asset growth have a negative effect on profitability. 2. From the results of simple linear regression analysis, it is known that liquidity and asset growth have a negative effect on profitability, profitability has a positive effect on firm value. 5. From the results of the correlation coefficient test and determination that there is a very low relationship between the independent variable liquidity and asset growth on the dependent variable profitability, From the results of the correlation coefficient test, it is known that there is a moderate relationship between profitability and firm value. 7. From the results of the F test, it is known that liquidity and asset growth have no significant effect on profitability. 8. From the results of the $t$ test, it is known that liquidity and asset growth have no significant effect on profitability, and profitability has a significant effect on firm value.
\end{abstract}

Keywords: Liquidity, Asset Growth, Profitability and Company Value

Article History: Received: 20 Desember 2021 Revised: 22 Desember 2021 Accepted: 23 Desember 2021 


\section{PENDAHULUAN}

Pertumbuhan dan perkembangan ekonomi saat ini menyebabkan persaingan antar perusahaan semakin ketat dalam mencapai tujuan yaitu meningkatkan laba. Untuk mewujudkan tujuan tersebut pihak manajemen perusahaan harus meningkatkan kinerja perusahaan dan memaksimalkan nilai perusahaan. Memaksimalkan nilai perusahaan sangatlah penting bagi perusahaan karena dengan memaksimalkan nilai perusahaan berarti juga memaksimalkan tujuan utama perusahaan.

Nilai perusahaan merupakan gambaran mengenai keadaan umum perusahaan dimana dapat memengaruhi persepsi investor terhadap perusahaan. Salah satu rasio yang berdampak pada nilai perusahaan adalah rasio profitabilitas. Profitabilitas merupakan kemampuan perusahaan untuk menghasilkan laba dengan memanfaatkan sumber daya yang dimiliki perusahaan.

Ada beberapa faktor yang mempengaruhi profitabilitas yaitu rasio likuiditas. Likuiditas merupakan kemampuan perusahaan dalam melunasi seluruh kewajiban jangka pendek perusahaan. Faktor lain yang mempengaruhi profitabilitas adalah rasio Pertumbuhan Aset. Pertumbuhan aset merupakan perbandingan antara total aset tahun ini dikurang dengan total aset tahun lalu dibagi dengan total aset tahun lalu.

Berikut ini disajikan gambaran likuiditas, Pertumbuhan Aset, Profitabilitas dan Nilai Perusahaan

Tabel 1

Gambaran Likuiditas, Pertumbuhan Aset, Profitabilitas dan Nilai Perusahaan pada Perusahaan Sub Sektor Pertambangan Minyak dan Gas Bumi yang Terdaftar di Bursa Efek Indonesia Periode 2015-2019

\begin{tabular}{|l|l|l|l|l|}
\hline Tahun & $\begin{array}{l}\text { CR } \\
\text { (Kali) }\end{array}$ & $\begin{array}{l}\text { AG } \\
\text { (Kali) }\end{array}$ & $\begin{array}{l}\text { ROE } \\
\text { (Kali) }\end{array}$ & $\begin{array}{l}\text { TobinsQ } \\
\text { (Kali) }\end{array}$ \\
\hline 2015 & 1,648 & 0,233 & $(0,120)$ & 0,832 \\
\hline 2016 & 1,411 & 0,145 & 0,854 & 0,891 \\
\hline 2017 & 1,702 & 0,077 & 0,015 & 0,873 \\
\hline
\end{tabular}

\begin{tabular}{|l|l|l|l|l|}
\hline 2018 & 1,519 & 0,085 & 0,038 & 0,822 \\
\hline 2019 & 1,420 & 0,004 & $(0,108)$ & 0,863 \\
\hline $\begin{array}{l}\text { Rata- } \\
\text { rata }\end{array}$ & $\mathbf{1 , 5 4 0}$ & $\mathbf{0 , 1 0 7}$ & $\mathbf{0 , 1 3 6}$ & $\mathbf{0 , 8 5 6}$ \\
\hline
\end{tabular}

Sumber:Laporan Keuangan Perusahaan Sub Sektor Pertambangn Minyak dan Gas Bumi (Data Diolah), 2021

Berdasarkan tabel 1 di atas diketahui bahwa variabel likuiditas mengalami Fluktuasi dan cenderung menurun, sementara profitabilitas mengalami fluktuasi dan cenderung menurun. Pada tahun 2019 likuiditas mengalami penurunan, sementara profitabilitas juga mengalami penurunan. Sedangkan variabel Pertumbuhan aset mengalami fluktuasi dan dan cenderung menurun, sementara profitabilitas juga mengalami fluktuasi dan cenderung menurun. Tahun 2016 pertumbuhan aset mengalami penurunan sedangkan profitabilitas mengalami peningkatan. Variabel profitabilitas mengalami fluktuasi dan cenderung menurun, sementara nilai perusahaan mengalami fluktuasi dan cenderung stabil. Pada tahun 2018 profitabilitas mengalami peningkatan sedangkan nilai perusahaan mengalami penurunan. Pada tahun 2019 profitabilitas mengalami penurunan sedangkan nilai perusahaan mengalami peningkatan.

\section{Identifikasi Masalah}

1. Rasio likuiditas pada tahun 2015-2019 mengalami fluktuasi dan cenderung menurun. Hal ini mengidentifikasi bahwa kemampuan perusahaan dalam memenuhi kewajiban jangka pendeknya menurun.

2. Rasio pertumbuhan aset pada tahun 2015-2019 mengalami fluktuasi dan cenderung menurun. Hal ini mengidentifikasi bahwa kemampuan perusahaan dalam mempertahankan aset menurun.

3. Rasio profitabilitas pada tahun 20152019 mengalami fluktuasi dan cenderung menurun. Hal ini mengidentifikasi bahwa kemampuan 
perusahaan dalam menghasilkan laba menurun.

4. Rasio nilai perusahaan pada tahun 2015-2019 mengalami fluktuasi dan cenderung stabil. Hal ini mengidentifikasi bahwa nilai perusahaan tidak terjadi perubahan yang signifikan.

5. Likuiditas, pertumbuhan aset dan profitabilitas pada tahun 2015-2019 berfluktuasi dan cenderung menurun. Hal ini mengidentifikasikan bahwa pengelolahan aset perusahaan belum optimal.

6. Likuiditas pada 2019 mengalami penurunan, sementara profitabilitas juga mengalami penurunan.

7. Pertumbuhan aset pada tahun 2016 mengalami penurunan, sedangkan profitabilitas mengalami peningkatan.

8. Profitabilitas pada tahun 2018 mengalami peningkatan, sedangkan nilai perusahaan mengalami penurunan.

9. Profitabilitas pada tahun 2019 mengalami penurunan, sedangkan nilai perusahaan mengalami peningkatan.

\section{Rumusan Masalah}

1. Bagaimana gambaran Likuiditas, Pertumbuhan Aset, Profitabilitas dan Nilai Perusahaan pada Perusahaan Sub Sektor Pertambangan Minyak dan Gas Bumi yang terdaftar di Bursa Efek Indonesia.

2. Bagaimana pengaruh Likuiditas dan Pertumbuhan Aset terhadap Profitabilitas pada Perusahaan Sub Sektor Pertambangan Minyak dan Gas Bumi yang terdaftar di Bursa Efek Indonesia baik secara simultan maupun parsial.

3. Bagaimana pengaruh Profitabilitas terhadap Nilai Perusahaan pada Perusahaan Sub Sektor Pertambangan Minyak dan Gas Bumi yang terdaftar di Bursa Efek Indonesia.

\section{Tujuan Penelitian}

1. Untuk mengetahui gambaran Likuiditas, Pertumbuhan Aset, Profitabilitas dan
Nilai Perusahaan pada Perusahaan Sub Sektor Pertambangan Minyak dan Gas Bumi yang terdaftar di Bursa Efek Indonesia.

2. Untuk mengetahui pengaruh Likuiditas dan Pertumbuhan Aset terhadap Profitabilitas pada Perusahaan Sub Sektor Pertambangan Minyak dan Gas Bumi yang terdaftar di Bursa Efek Indonesia baik secara simultan maupun parsial.

3. Untuk mengetahui pengaruh Profitabilitas terhadap Nilai Perusahaan pada Perusahaan Sub Sektor Pertambangan Minyak dan Gas Bumi yang terdaftar di Bursa Efek Indonesia.

\section{LANDASAN TEORI Manajemen}

(Sinambela and Sinambela, 2019), menyatakan manajemen itu adalah suatu ilmu pengetahuan yang sistematis agar dapat memahami mengapa dan bagaimana manusia saling bekerja sama agar dapat menghasilkan sesuatu yang bermanfaat bagi orang lain maupun golongan tertentu dan masyarakat luas.

\section{Manajemen Keuangan}

(Sudana, 2011), manajemen keuangan perusahaan merupakan salah satu bidang manajemen fungsional perusahaan yang berhubungan dengan pengambilan keputusan investasi jangka panjang, keputusan pendanaan jangka panjang dan pengelolaan modal kerja perusahaan yang meliputi investasi dan pendanaan jangka pendek.

\section{Likuiditas}

Menurut (Horne and Wachowicz, 2012), likuiditas merupakan rasio untuk mengukur kemampuan perusahaan dalam memenuhi liabilitas jangka pendeknya.

\section{Pertumbuhan Aset}

Menurut penelitian yang dilakukan oleh (Khoiriyah and Rasyid, 2020), pertumbuhan aset adalah perubahan (peningkatan atau penurunan) total aset yang dimiliki perusahaan. Perusahaan yang 
asetnya dapat digunakan sebagai agunan utang cenderung menggunakan utang yang relatif besar. Semakin tinggi pertumbuhan aset maka akan semakin tinggi stuktur modalnya.

\section{Profitabilitas}

(Sudana, 2011), rasio profitabilitas merupakan rasio yang mengukur kemampuan perusahaan untuk menghasilkan laba dengan menggunakan sumber-sumber yang dimiliki perusahaan, seperti aktiva, modal atau penjualan perusahaan.

\section{Nilai Perusahaan}

(Brigham and Houston, 2012), rasio nilai pasar (market value ratio) berhubungan dengan harga saham perusahaan terhadap laba, arus kas dan nilai buku per sahamnya.

Pengaruh Likuiditas dan Pertumbuhan Aset Terhadap Profitabilitas

Dalam peningkatan profitabilitas ada beberapa faktor yang perlu dipertimbangkan oleh investor yang dijadikan acuan dalam menilai suatu sahan yaitu likuiditas dan pertumbuhan aset suatu perusahaan.

Menurut (Horne and Wachowicz, 2012), yang menyatakan bahwa likuiditas berbanding terbalik dengan profitabilitas. Artinya semakin tinggi likuiditas perusahaan maka kemampuan perusahaan dalam menghasilkan laba semakin rendah, begitu juga sebaliknya semakin rendah likuiditas maka kemampuan perusahaan dalam menghasilkan laba semakin tinggi.

Penelitian ini diperkuan oleh (Gultom et al., 2020), yang menunjukkan bahwa likuiditas, cash flow dan pertumbuhan penjualan berpengaruh positif dan signifikan terhadap profitabilitas.

\section{Pengaruh Profitabilitas Terhadap Nilai Perusahaan}

Profitabilitas merupakan rasio yang dipakai dalam mengukur kemampuan perusahaan untuk memperoleh laba.
Menurut (Brigham and Houston, 2012), jika rasio likuiditas, manajemen aset, manajemen utang, dan profitabilitas semuanya terlihat baik dan jika kondisi ini berjalan terus menerus secara stabil maka rasio nilai pasar juga akan tinggi, harga saham kemungkinan tinggi sesuai dengan yang diperkirakan, dan manajemen telah melakukan pekerjaannya dengan baik sehingga mendapat imbalan.

Penelitian ini diperkuat oleh (Dhani and Utama, 2017), menunjukkan bahwa profitabilitas berpengaruh positif dan signifikan terhadap nilai perusahaan.

\section{METODE}

Penelitian ini menggunakan desain penelitian kepustakaan (library research). Penelitian ini dilakukan dengan menggunakan metode analisis deskriptif kualitatif dan analisis deskriptif kuantitatif. Teknik analisis yang digunakan adalah uji asumsi klasik, analisis regresi linier berganda, analisis regresi linier sederhana, koefisien korelasi, koefisien determinasi dan uji hipotesis.

\section{HASIL DAN PEMBAHASAN}

Analisis Deskriptif Kualitatif

Gambarkan grafik Current Ratio

(CR) per tahun sebagai berikut:

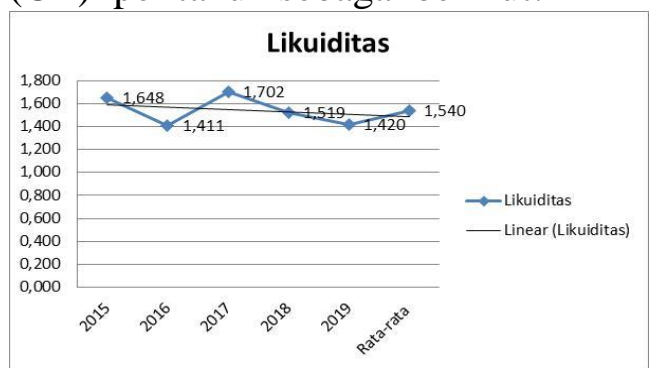

Sumber: Data Diolah, 2021

Gambar 1

Grafik Current Ratio (CR) Perusahaan Sub Sektor Pertambangan Minyak dan Gas Bumi yang Terdaftar di Bursa Efek Indonesia Periode 2015-2019

Berdasarkan gambar 1 di atas, secara keseluruhan dapat dilihat bahwa nilai likuiditas yang diukur dengan Current Ratio (CR) mengalami fluktuasi dan cenderung menurun. Hal ini disebabkan 
karena kewajiban lancar lebih besar dibandingkan dengan aset lancar.

Berikut ini digambarkan grafik aset growth (AG) pada gambar dibawah ini:

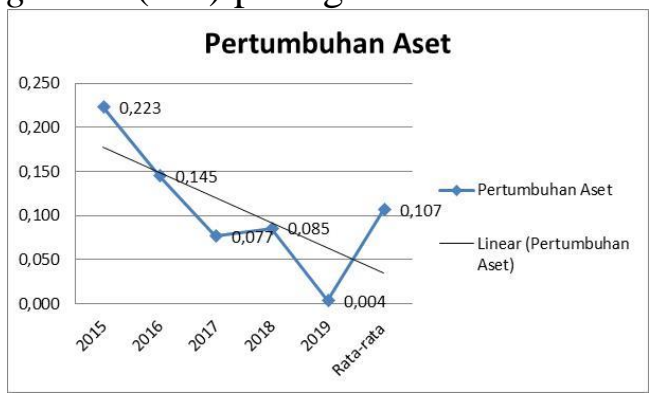

Sumber: Data Diolah, 2021

Gambar 2

Grafik Asset Growth (AG) Perusahaan Sub Sektor Pertambangan Minyak dan Gas Bumi yang Terdaftar di Bursa Efek Indonesia Periode 2015-2019

Berdasarkan gambar 2 di atas, secara keseluruhan dapat dilihat bahwa nilai pertumbuhan aset yang diukur dengan asset growth (AG) mengalami fluktuasi dan cenderung menurun. Hal ini disebabkan menurunnya total aset tahun ini sedangkan total aset tahun lalu meningkat.

Berikut ini dapat digambarkan grafik Return On Equity (ROE) sebagai berikut:

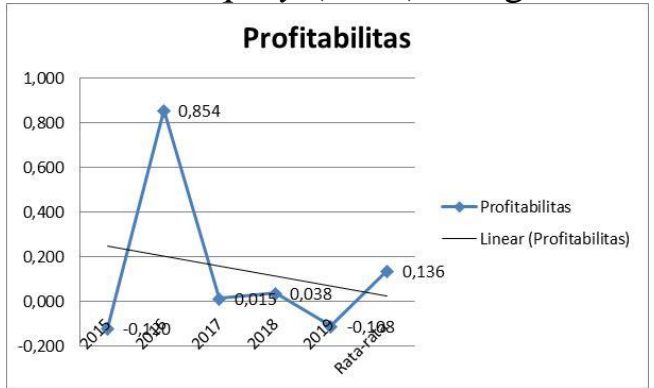

Sumber: Data Diolah, 2021

\section{Gambar 3}

Grafik Return on Equity (ROE)

Perusahaan Sub Sektor Pertambangan Minyak dan Gas Bumi yang Terdaftar di Bursa Efek Indonesia Periode 20152019

Berdasarkan gambar 3 di atas, secara keseluruhan dapat dilihat bahwa nilai profitabilitas mengalami fluktuasi dan cenderung menurun. Hal ini disebabkan karena peningkatan total ekuitas yang lebih tinggi dibandingkan dengan peningkatan laba bersih setelah pajak.
Berikut ini dapat digambarkan grafik Tobins Q sebagai berikut:

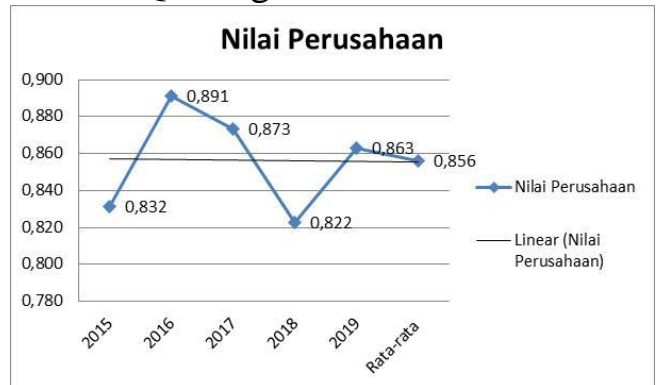

Sumber: Data Diolah, 2021

Gambar 4

Grafik Tobins Q Perusahaan Sub Sektor Pertambangan Minyak dan Gas Bumi yang Terdaftar di Bursa Efek Indonesia Periode 2015-2019

Berdasarkan gambar 4 di atas, secara keseluruhan dapat dilihat bahwa nilai perusahaan mengalami fluktuasi dan cenderung stabil. Hal ini disebabkan karena nilai harga saham, jumlah saham beredar, total hutang dan total aset mengalami peningkatan dan penurunan secara konstan setiap tahunnya.

\section{Analisis Deskriptif Kuantitatif} Analisis Regresi Linear

1. Analisis Regresi Linear berganda

Pengujian analisis regresi linear berganda pada penelitian ini dengan hasil yang terlihat pada Tabel 2:

Tabel 2

Hasil Analisis Regresi Linear Berganda Likuiditas dan Pertumbuhan Aset Terhadap Profitabilitas

\begin{tabular}{|l|r|r|c|}
\hline \multirow{2}{*}{ Model } & \multicolumn{2}{|c|}{$\begin{array}{c}\text { Unstandardized } \\
\text { Coefficients }\end{array}$} & $\begin{array}{c}\text { Standardized } \\
\text { Coefficients }\end{array}$ \\
\cline { 2 - 4 } & \multicolumn{1}{c|}{ B } & \multicolumn{1}{c|}{$\begin{array}{c}\text { Std. } \\
\text { Error }\end{array}$} & \multicolumn{1}{c|}{ Beta } \\
\hline (Constant) & $\mathbf{, 2 4 0}$ &, 285 & \\
CR & $\mathbf{- , 0 4 2}$ &, 142 &,- 053 \\
AG & $\mathbf{- , 3 6 5}$ &, 567 &,- 115 \\
\hline
\end{tabular}

Sumber:Hasil Pengolahan Data (SPSS 21)

Berdasarkan tabel di atas model persamaan regresi yang diperoleh adalah: $\mathrm{Y}=0,240-0,042 \mathrm{X}_{1}-0,365 \mathrm{X}_{2}$ artinya likuiditas dan pertumbuhan aset berpengaruh negatif terhadap profitabilitas.

2. Analisis Regresi Linear Sederhana 
Hasil analisis regresi linear sederhana pada penelitian ini sebagai berikut ini:

Tabel 3

Hasil Analisis Regresi Linear Sederhana Likuiditas Terhadap Profitabilitas

\begin{tabular}{|l|r|r|r|}
\hline \multicolumn{1}{|c|}{ Model } & \multicolumn{2}{|c|}{$\begin{array}{c}\text { Unstandardized } \\
\text { Coefficients }\end{array}$} & $\begin{array}{c}\text { Standardized } \\
\text { Coefficients }\end{array}$ \\
\cline { 2 - 4 } & $\mathbf{B}$ & $\begin{array}{c}\text { Std. } \\
\text { Error }\end{array}$ & Beta \\
\hline (Constant) & $\mathbf{, 2 3 0}$ &, 282 & \\
CR & $\mathbf{- , 0 6 1}$ &, 138 &,- 077 \\
\hline
\end{tabular}

Sumber: Hasil Pengolahan Data (SPSS 21)

Berdasarkan tabel di atas model persamaan regresi linear sederhana dapat di bentuk sebagai berikut: $Y=0,230-$ $0,061 \mathrm{X}$ artinya likuiditas berpengaruh negatif terhadap profitabilitas.

Tabel 4

Hasil Analisis Regresi Linear Sederhana

Pertumbuhan Aset Terhadap

\section{Profitabilitas}

\begin{tabular}{|l|l|r|l|}
\hline Model & \multicolumn{2}{|l|}{$\begin{array}{l}\text { Unstandardized } \\
\text { Coefficients }\end{array}$} & $\begin{array}{l}\text { Standardized } \\
\text { Coefficients }\end{array}$ \\
\cline { 2 - 4 } & B & \multicolumn{1}{l|}{$\begin{array}{l}\text { Std. } \\
\text { Error }\end{array}$} & Beta \\
\hline (Constant) & $\mathbf{0 , 1 7 9}$ &, 194 & \\
AG & $\mathbf{- , 4 0 0}$ &, 547 & \\
\hline
\end{tabular}

Sumber:Hasil Pengolahan Data (SPSS 21)

Berdasarkan tabel di atas model persamaan regresi linear sederhana dapat di bentuk sebagai berikut: $Y=0,179$ $0,400 \mathrm{X}$ artinya pertumbuhan aset berpengaruh negatif terhadap profitabilitas.

Tabel 5

Hasil Analisis Regresi Linear Sederhana Profitabilitas Terhadap Nilai

\section{Perusahaan}

\begin{tabular}{|l|r|r|r|}
\hline \multirow{2}{*}{ Model } & \multicolumn{2}{|c|}{$\begin{array}{c}\text { Unstandardized } \\
\text { Coefficients }\end{array}$} & $\begin{array}{c}\text { Standardized } \\
\text { Coefficients }\end{array}$ \\
\cline { 2 - 4 } & \multicolumn{1}{c|}{ B } & \multicolumn{1}{c|}{$\begin{array}{c}\text { Std. } \\
\text { Error }\end{array}$} & \multicolumn{1}{c|}{ Beta } \\
\hline (Constant) & $\mathbf{, 8 4 8}$ &, 024 & \\
ROE & $\mathbf{0 5 9}$ &, 022 &, 416 \\
\hline
\end{tabular}

Sumber:Hasil Pengolahan Data (SPSS 21)

Berdasarkan tabel di atas model persamaan regresi linear sederhana dapat di bentuk sebagai berikut: $Z=0,848+$ $0,059 \mathrm{Y}$ artinya profitabilitas berpengaruh positif terhadap nilai perusahaan.

\section{Koefisien dan Determinasi}

Nilai $r$ hitung dapat dihitung dengan program SPSS Versi 21.

Tabel 6

Hasil Analisis Koefisien Korelasi dan

Koefisien Determinasi Likuiditas dan Pertumbuhan Aset dengan Profitabilitas

\begin{tabular}{|l|c|r|r|r|}
\hline Model & $\mathrm{R}$ & $\begin{array}{c}\mathrm{R} \\
\text { Square }\end{array}$ & $\begin{array}{r}\text { Adjusted } \\
\text { R Square }\end{array}$ & $\begin{array}{c}\text { Std. Error } \\
\text { of the } \\
\text { Estimate }\end{array}$ \\
\hline 1 & $\mathbf{, 1 3 7}^{\mathbf{a}}$ & $\mathbf{, 0 1 9}$ &,- 043 & 1,110400 \\
\hline
\end{tabular}

Sumber:Hasil Pengolahan Data (SPSS 21)

Berdasarkan tabel di atas dapat dilihat bahwa nilai korelasi (r) adalah 0,137 yang artinya bahwa terdapat hubungan yang sangat rendah antara variabel bebas likuiditas dan pertumbuhan aset terhadap variabel terikat profitabilitas. Sementara koefisien determinasi (R Square) adalah 0,019 (1,9\%) yang berarti variabel bebas dapat menjelaskan variabel terikat sebesar 0,019 (1,9\%), sedangkan sisanya $0,981 \quad(98,1 \%)$ dijelaskan di variabel lainnya

\section{Tabel 7}

Hasil Analisis Koefisien Korelasi dan Korelasi Determinasi Profitabilitas dengan Nilai Perusahaan

\begin{tabular}{|l|c|r|r|c|}
\hline Model & $\mathrm{R}$ & $\begin{array}{c}\mathrm{R} \\
\text { Square }\end{array}$ & $\begin{array}{r}\text { Adjusted } \\
\text { R Square }\end{array}$ & $\begin{array}{c}\text { Std. Error } \\
\text { of the } \\
\text { Estimate }\end{array}$ \\
\hline 1 & $\mathbf{, 1 6}^{\mathbf{a}}$ & $\mathbf{, 1 7 3}$ &, 148 &, 142666 \\
\hline
\end{tabular}

Sumber: Hasil Pengolahan Data (SPSS 21) Berdasarkan tabel di atas dapat dilihat bahwa nilai korelasi (r) adalah 0,416 yang artinya bahwa terdapat hubungan yang sedang antara variabel bebas profitabilitas terhadap variabel terikat nilai perusahaan. Sementara koefisien determinasi ( $\mathrm{R}$ Square) adalah $0,173(17,3 \%)$ yang berarti variabel bebas profitabilitas dapat menjelaskan variabel terikat sebesar $0,173(17,3 \%)$, sedangkan sisanya sebesar $0,827(82,7 \%)$ dijelaskan oleh variabel lainnya

\section{Uji Hipotesis}

Uji Simultan (Uji F)

Hasil uji $F$ dalam penelitian ini sebagai berikut:

Tabel 8 
Hasil Uji F

ANOVA $^{\mathrm{a}}$

\begin{tabular}{|ll|r|c|}
\hline \multicolumn{1}{|c|}{ Model } & F & Sig. \\
\hline \multirow{2}{*}{$\begin{array}{l}\text { Regression } \\
\text { Residual } \\
\text { Total }\end{array}$} & $\mathbf{3 0 4}$ & $\mathbf{7 4 0}^{\mathbf{b}}$ \\
\hline
\end{tabular}

Sumber: Hasil Pengolahan Data (SPSS 21)

Berdasarkan tabel di atas dapat dilihat nilai $F_{\text {hitung }}$ sebesar 0,304 . Dengan tingkat signifikan 0,740 yang lebih besar dari $\alpha=0,05$ atau dapat dikatakan $0,740>$ 0,005 sedangkan nilai $\mathrm{F}_{\text {tabel }}(35-2-1=32)$ sebesar 3,29. Karena $F_{\text {hitung }}<F_{\text {tabel }}(0,304<$ $3,29)$ maka $\mathrm{H}_{0}$ diterima yang berarti bahwa likuiditas dan pertumbuhan aset berpengaruh tidak signifikan terhadap profitabilitas.

\section{Uji Parsial (Uji T)}

Hasil uji parsial dalam penelitian ini sebagai berikut:

Tabel 9

Hasil Uji t Likuiditas terhadap Profitabilitas

\begin{tabular}{|ll|r|r|}
\hline \multicolumn{1}{|c|}{ Model } & \multicolumn{1}{|c|}{ T } & \multicolumn{1}{|c|}{ Sig } \\
\hline \multirow{2}{*}{1} & (Constant) &, 816 &, 420 \\
& CR & $\mathbf{- , 4 4 5}$ &, 659 \\
\hline
\end{tabular}

Sumber:Hasil Pengolahaan Data (SPSS 21)

Berdasarkan hasil uji t pada tabel di atas nilai thitung pada variabel $\mathrm{X}_{1}$ sebesar 0,445 . Sedangkan untuk $t_{\text {tabel }}$ dengan tingkat signifikasi 5\%, n-k-1 atau 35-1-1 = 33 diperoleh angka tabel sebesar 2,03452 atau dengan taraf signifikan $0,659>0,05$ maka $\mathrm{H}_{0}$ diterima. Hal ini berarti likuiditas berpengaruh tidak signifikan terhadap profitabilitas.

\section{Tabel 10 \\ Hasil Uji t Pertumbuhan Aset terhadap Profitabilitas}

Sumber:Hasil Pengolahaan Data (SPSS 21)

Berdasarkan hasil uji t pada tabel di atas dapat nilai thitung pada variabel $\mathrm{X}_{2}$ sebesar -0,731. Sedangkan untuk $t_{\text {tabel }}$ dengan tingkat signifikasi $5 \%, \mathrm{n}-\mathrm{k}-1$ atau $35-1-1=33$ diperoleh angka $t_{\text {tabel }}$ sebesar 2,03452 atau dengan taraf signifikan 0,470 $>0,05$ maka $\mathrm{H}_{0}$ diterima. Hal ini berarti pertumbuhan aset berpengaruh tidak signifikan terhadap profitabilitas.
Tabel 11

Hasil Uji t Profitabilitas terhadap Nilai Perusahaan

\begin{tabular}{|rl|r|r|}
\hline \multicolumn{1}{|c|}{ Model } & \multicolumn{1}{|c|}{ T } & \multicolumn{1}{c|}{ Sig } \\
\hline \multirow{2}{*}{1} & (Constant) & 34,894 &, 000 \\
& ROE & $\mathbf{2 , 6 2 7}$ & $\mathbf{, 0 1 3}$ \\
\hline
\end{tabular}

Sumber:Hasil Pengolahaan Data (SPSS 21) Berdasarkan hasil uji t pada table di atas nilai $t_{\text {hitung }}$ pada variabel $X$ sebesar 2,627. Sedangkan untuk $t_{\text {tabel }}$ dengan tingkat signifikasi 5\%, n-k-1 atau 35-1-1 = 33 diperoleh angka $t_{\text {tabel }}$ sebesar 2,03452 atau dengan taraf signifikan $0,013<0,05$ maka $\mathrm{H}_{0}$ ditolak. Hal ini berarti profitabilitas berpengaruh signifikan terhadap nilai perusahaan.

\section{Evaluasi}

Evaluasi Likuiditas pada Perusahaan Sub Sektor Pertambangan Minyak dan Gas Bumi yang Terdaftar di Bursa Efek Indonesia Periode 2015-2019

Hasil analisis nilai likuiditas yang diukur dengan Curent Ratio (CR) mengalami fluktuasi dan cenderung menurun. Hal ini disebabkan karena kewajiban lancar lebih besar dibandingkan dengan aset lancar.

Nilai rata-rata likuiditas Perusahaan sebesar 1,540 kali yang artinya bahwa setiap Rp 1 hutang lancar dijamin oleh aset lancar sebesar $\mathrm{Rp}$ 1,540. Nilai likuiditas minimum perusahaan adalah sebesar 0,052 kali yang artinya bahwa setiap Rp 1 hutang lancar dijamin oleh aset lancar sebesar Rp 0,052. Hal ini disebabkan pada tahun tersebut terjadi penurunan tingkat aset lancar seperti kas dan setara kas, piutang

\begin{tabular}{|ll|r|r|}
\hline \multicolumn{1}{|c|}{ Model } & \multicolumn{1}{|c|}{ T } & \multicolumn{1}{c|}{ Sig } \\
\hline \multirow{2}{1}{1} & (Constant) &, 920 &, 364 \\
& AG & $\mathbf{- , 7 3 1}$ & $\mathbf{4 7 0}$ \\
\hline
\end{tabular}

lain-lain, persediaan dan pajak dibayar dimuka cenderung lebih tinggi dibandingkan dengan penurunan hutang lancar seperti hutang usaha, pendapatan diterima dimuka dan biaya yang masih harus dibayar. 
Evaluasi Pertumbuhan Aset Pada Perusahaan Sub Sektor Pertambangan Minyak dan Gas Bumi yang Terdaftar di Bursa Efek Indonesia Periode 20152019

Hasil analisis nilai pertumbuhan aset yang diukur dengan Asset growth (AG) mengalami fluktuasi dan cenderung menurun. Hal ini disebabkan menurunnya total aset tahun ini sedangkan total aset tahun lalu meningkat

Nilai rata-rata pertumbuhan aset Perusahaan periode 2015-2019 adalah sebesar 0,107 kali yang artinya bahwa setiap Rp 1 pertumbuhan aset tahun ini dijamin oleh pertumbuhan aset tahun ini sebesar Rp 0,107. Nilai pertumbuhan aset minimum Perusahaan sebesar -0,337 kali yang artinya perusahaan mengalami penurunan pertumbuhan aset sebesar 0,337 kali dari tahun sebelumnya. Meningkatkan pertumbuhan aset, sebaiknya perusahaan berupaya meningkatkan penjuaalan dengan memperluas target pasar dan mengembangkan kualitas produk agar pelanggan tertarik dan laba meningkat, maka perusahaan dapat melakukan investasi sehingga aset perusahaan akan meningkat

Evaluasi Profitabilitas Pada Perusahaan Sub Sektor Pertambangan Minyak dan Gas Bumi yang Terdaftar di Bursa Efek Indonesia Periode 2015-2019

Hasil analisis nilai profitabilitas yang diukur dengan Return On Equity (ROE) berfluktuasi dan cederung menurun. Hal ini disebabkan karena peningkatan total ekuitas perusahaan lebih tinggi dibandingkan dengan peningkatan laba bersih setelah pajak.

Nilai rata-rata profitabilitas adalah sebesar 0,136 kali yang artinya bahwa setiap Rp 1 total ekuitas yang dikelola dapat dihasilkan laba setelah pajak sebesar Rp 0,136. Nila minimum profitabilitas adalah sebesar -1,232 yang berarti bahwa setiap Rp 1 total ekuitas mengakibatkan kerugian sebesar $\mathrm{Rp}$ 1,232. Hal ini disebabkan karena penurunan laba bersih setelah pajak lebih besar dibandingkan penurunan total ekuitas seperti penghasilan komprehensif dan saldo laba.

Evaluasi Nilai Perusahaan Pada Perusahaan Sub Sektor Pertambangan Minyak dan Gas Bumi yang Terdaftar di Bursa Efek Indonesia Periode 20152019

Hasil analisis nilai perusahaan yang diukur dengan TOBINS Q berfluktuasi dan cenderung stabil. Hal ini disebabkan karena nilai harga saham, jumlah saham beredar, total hutang dan total aset mengalami peningkatan dan penurunan secara konstan setiap tahunnya.

Rata-rata nilai perusahaan adalah sebesar 0,586 kali yang artinya harga pasar saham dan nilai buku dari total hutang dihargai sebesar 0,586 dari nilai total aset. Nilai minimum nilai perusahaan adalah sebesar 0,454 yang berarti setiap 1 harga pasar saham dihargai lebih rendah dari nilai buku dan total hutang sebesar 0,454 dari nilai total asetnya. Hal ini disebabkan karena harga pasar saham dan jumlah saham beredar tetap, total hutang cenderung menurun lebih tinggi dibandingkan dengan penurunan total aset sehingga nilai perusahaan mengalami penurunan.

Evaluasi Pengaruh Likuiditas dan Pertumbuhan Aset Terhadap Profitabilitas Pada Perusahaan Sub Sektor Pertambangan Minyak dan Gas Bumi yang Terdaftar di Bursa Efek Indonesia Periode 2015-2019

Berdasarkan hasil pengujian analisis regresi linier berganda yang telah dilakukan, dapat diketahui bahwa likuiditas dan pertumbuhan aset berpengaruh negatif terhadap profitabilitas. Hal ini dapat dilihat pada persamaan regresi linier berganda yaitu: $\mathbf{Y}=\mathbf{0 , 2 4 0}-$ $\mathbf{0 , 0 4 2 X} \mathbf{X}_{1}-\mathbf{0 , 3 6 5 X _ { 2 }}$ besarnya pengaruh likuiditas dan pertumbuhan aset yang diukur dengan Current Ratio (CR) dan Asset Growth (AG) adalah sebesar 0,240 yang berarti bahwa setiap likuiditas dan pertumbuhan aset meningkat sebesar 1 
satuan, maka profitabilitas akan menurun sebesar 0,240 satuan dengan asumsi variabel bebas sama dengan nol

Hal ini sejalan dengan pendapat (Horne and Wachowicz, 2012), yang menyatakan bahwa likuiditas berbanding terbalik dengan profitabilitas. Artinya semakin tinggi likuiditas perusahaan maka kemampuan perusahaan dalam menghasilkan laba semakin rendah, begitu juga sebaliknya semakin rendah likuiditas maka kemampuan perusahaan dalam menghasilkan laba semakin tinggi.

\section{Evaluasi Pengaruh Profitabilitas Terhadap Nilai Perusahaan Pada Perusahaan Sub Sektor Pertambangan Minyak dan Gas Bumi yang Terdaftar di Bursa Efek Indonesia Periode 2015- 2019}

Berdasarkan hasil pengujian analisis regresi linier sederhana yang telah dilakukan, dapat diketahui bahwa profitabilitas berpengaruh positif terhadap nilai perusahaan. Hal ini dapat dilihat pada persamaan regresi linier sederhana yaitu: $\mathbf{Z}$ $=0,848+0,059 Y$ besarnya pengaruh profitabilitas yang diukur dengan ROE adalah sebesar 0,848 yang berarti bahwa setiap profitabilitas meningkat sebesar 1 satuan maka nilai perusahaan akan meningkat sebesar 0,848 dengan asumsi variabel bebas sama dengan nol. Profitabilitas sebagai Y adalah sebesar 0,059 yang berarti setiap profitabilitas meningkat sebesar 1 satuan maka nilai perusahaan akan mengalami kenaikan sebesar 0,059.

Hal ini sejalan dengan pendapat (Brigham and Houston, 2012), jika rasio likuiditas, manajemen aset, manajemen utang, dan profitabilitas semuanya terlihat baik dan jika kondisi ini berjalan terus menerus secara stabil maka rasio nilai pasar juga akan tinggi, harga saham kemungkinan tinggi sesuai dengan yang diperkirakan, dan manajemen telah melakukan pekerjaannya dengan baik sehingga mendapat imbalan.

\section{KESIMPULAN DAN SARAN}

\section{Kesimpulan}

1. Berdasarkan hasil penelitian secara keseluruhan nilai rata-rata Current Ratio (CR) mengalami fluktuasi dan cenderung menurun.

2. Berdasarkan hasil penelitian secara keseluruhan nilai rata-rata Asset Growth (AG) mengalami fluktuasi dan cenderung menurun.

3. Berdasarkan hasil penelitian secara keseluruhan nilai rata-rata Return on Equity (ROE) mengalami fluktuasi dan cenderung menurun.

4. Berdasarkan hasil penelitian secara keseluruhan nilai rata-rata Tobins $Q$ mengalami fluktuasi dan cenderung stabil.

5. Dari hasil analisis regresi linier berganda diketahui bahwa likuiditas dan pertumbuhan aset berpengaruh negatif terhadap profitabilitas.

6. Dari hasil analisis regresi linier sederhana diketahui bahwa likuiditas dan pertumbuhan aset berpengaruh negatif terhadap profitabilitas, profitabilitas berpengaruh positif terhadap nilai perusahaan

7. Dari hasil uji koefisien korelasi dan determinasi bahwa terdapat hubungan yang sangat rendah antara variabel bebas likuiditas dan pertumbuhan aset terhadap variabel terikat profitabilitas. Sementara koefisien determinasi bahwa profitabilitas dapat dijelaskan oleh variabel likuiditas dan pertumbuhan aset. Dari hasil uji koefisien korelasi diketahui bahwa terdapat hubungan yang sedang antara profitabilitas terhadap nilai perusahaan. Sementara koefisien determinasi bahwa nilai perusahaan dapat dijelaskan oleh variabel profitabilitas.

8. Dari hasil uji $\mathrm{F}$ diketahui bahwa likuiditas dan pertumbuhan aset berpengaruh tidak signifikan terhadap profitabilitas.

9. Dari hasil uji t diketahui bahwa likuiditas dan pertumbuhan aset berpengaruh tidak signifikan terhadap profitabilitas, dan profitabilitas 
berpengaruh signifikan terhadap nilai perusahaan.

\section{Saran}

1. untuk meningkatkan likuiditas sebaiknya perusahaan meningkatkan aset lancarnya dengan melakukan kegiatan penjualan yang dapat memberikan kontribusi laba secara tunai maupun berbentuk piutang usaha untuk meningkatkan likuiditas perusahaan.

2. Untuk meningkatkan pertumbuhan aset sebaiknya perusahaan berupaya meningkatkan penjualan dengan memperluas target pasar dan mengembangkan kualitas produk agar pelanggan tertarik dan laba perusahaan meningkat, dengan laba yang meningkat maka perusahaan dapat melakukan investasi sehingga aset perusahaan akan meningkat.

3. Untuk meningkatkan profitabilitas sebaiknya perusahaan mampu meningkatkan penjualan dan mengoptimalkan pengelolaan total aset perusahaan maka perusahaan mampu mencapai tingkat laba yang lebih maksimal.

4. Untuk meningkatkan nilai perusahaan sebaiknya Perusahaan mampu meningkatkan pengelolaan aset dan mengendalikan penggunaan utang perusahaan secara efektif sehingga dapat meningkatkan laba perusahaan.

\section{DAFTAR PUSTAKA}

Brigham, E. F. and Houston, J. F. (2012) Dasar-dasar Manajemen Keuangan Essentials Of Financial Management. Sebelas. Jakarta: Salemba Empat.

Dhani, I. P. and Utama, A. . G. S. (2017) 'Pengaruh Pertumbuhan Perusahaan, Struktur Modal, Dan Profitabilitas Terhadap Nilai Perusahaan', Jurnal Riset Akuntansi Dan Bisnis Airlangga, 2(1), pp. 135-148. doi: 10.31093/jraba.v2i1.28.
Gultom, S. M. J. T. et al. (2020) 'Pengaruh Likuiditas , Cash Flow Dan Pertumbuhan Penjualan Terhadap Profitabilitas Pada Perusahaan Pertanian', Jurnal Riset Akuntansi \& Keuangan Dewantara, 3(2), pp. 164 173.

doi:https://doi.org/10.26533/jad.v3i2. 698.

Horne, J. C. Van and Wachowicz, J. M. W. (2012) Prinsip-prinsip Manajemen Keuangan. Tiga Belas. Edited by E. S. Suharsi. Jakarta: Salemba Empat.

Khoiriyah, D. and Rasyid, R. (2020) 'Pengaruh Risiko Bisnis, Profitabilitas dan Pertumbuhan Aset terhadap Struktur Modal Perusahaan yang Terdaftar di Jakarta Islamic Index', Jurnal Kajian Manajemen dan Wirausaha, 2(2), p. 43. doi: 10.24036/jkmw0284920.

Sinambela, L. P. and Sinambela, S. (2019) Manajemen Kinerja Pengelolaan, Pengukuran dan Impikasi Kinerja. Pertama. Depok: Raja Grafindo Persada.

Sudana, I. M. (2011) Manajemen Keuangan Perusahaan Teori \& Praktik. Edited by N. I. Sallama. Jakarta: Erlangga.

\section{PROFIL SINGKAT}

Ady Inrawan, was born in Pematangsiantar on February 10, 1970. Graduated with a Bachelor of Economics in 2009 from the Sultan Agung College of Economics and in 2013 graduated with a Masters in Management from HKBP Nommensen University. The author is a permanent lecturer at the Sultan Agung Pematangsiantar College of Economics in the Management S-1 Study Program. Darwin Lie, is the Chairman of STIE Sultan Agung and senior researcher. $\mathrm{He}$ earned doctoral in Pasundan University with a concentration in management 
science. His research interests include strategy management, human resource management, organizational behavior, entrepreneurship, business economics, service quality management, consumer behavior and financial management. Debi Eka Putri, Born in Pematangsiantar, a city in North Sumatra province on August 03, 1993. In 2014 she completed a Bachelor of Economics (SE) majoring in Management at the Sultan Agung High School of Economics Pematangsiantar. Then successfully completed a Master of Management with a concentration in Financial Management at the Muhammadiyah University of North Sumatra (UMSU), Medan in 2017. His daily activities are currently actively teaching at the Sultan Agung Pematangsiantar School of Economics. Suci Indah Rukmana, Lahir di Kota Pematangsiantar, 01 Desember 1998 memiliki zodiak Sagitarius. Ia seorang lulusan Sarjana Ekonomi dengan jurusan Manajemen dengan konsentrasi Manajemen Keuangan di Sekolah Tinggi Ilmu Ekonomi (STIE) Sultan Agung Pematangsiantar tahun 2021. Membantu usaha menjahit orang tua merupakan aktivitasnya saat ini disamping sedang berusahan mendapatkan pekerjaan yang memiliki janjang karir yang baik untuk masa depannya. 